\title{
Regulatory changes in South Africa and their impact on the short-term insurance environment, 1960-1980
}

\begin{tabular}{|c|c|}
\hline \multicolumn{2}{|c|}{$\begin{array}{l}\text { Authors: } \\
\text { Yolande Hagedo } \\
\text { Grietjie Verhoef } \\
\text { Gideon } \text { Els }^{3} \text { (D) }\end{array}$} \\
\hline \multicolumn{2}{|c|}{$\begin{array}{l}\text { Affiliations: } \\
{ }^{1} \text { Private, Johannesburg, } \\
\text { South Africa }\end{array}$} \\
\hline \multicolumn{2}{|c|}{$\begin{array}{l}{ }^{2} \text { Department of Economic, } \\
\text { Business and Accounting } \\
\text { History, University of } \\
\text { Johannesburg, Johannesburg } \\
\text { South Africa }\end{array}$} \\
\hline \multicolumn{2}{|c|}{$\begin{array}{l}{ }^{3} \text { Department of Accountancy, } \\
\text { University of Johannesburg, } \\
\text { Johannesburg, South Africa }\end{array}$} \\
\hline \multicolumn{2}{|c|}{$\begin{array}{l}\text { Research Project Registration: } \\
\text { Project number: } 423\end{array}$} \\
\hline \multicolumn{2}{|c|}{$\begin{array}{l}\text { Corresponding author: } \\
\text { Yolande Hagedorn-Hansen, } \\
\text { yolandehansen13@gmail. } \\
\text { com }\end{array}$} \\
\hline \multicolumn{2}{|c|}{$\begin{array}{l}\text { Dates: } \\
\text { Received: } 22 \text { Feb. } 2019 \\
\text { Accepted: } 02 \text { Oct. } 2019 \\
\text { Published: } 12 \text { Dec. } 2019\end{array}$} \\
\hline \multicolumn{2}{|c|}{$\begin{array}{l}\text { How to cite this article: } \\
\text { Hagedorn-Hansen, Y., } \\
\text { Verhoef, G. \& Els, G., 2019, } \\
\text { 'Regulatory changes in South } \\
\text { Africa and their impact on } \\
\text { the short-term insurance } \\
\text { environment, 1960-1980', } \\
\text { Journal of Economic and } \\
\text { Financial Sciences 12(1), } \\
\text { a458. https://doi.org/10. } \\
\text { 4102/jef.v12i1.458 }\end{array}$} \\
\hline \multicolumn{2}{|c|}{$\begin{array}{l}\text { Copyright: } \\
\text { (C) 2019. The Authors. } \\
\text { Licensee: AOSIS. This } v \\
\text { is licensed under the } \\
\text { Creative Commons } \\
\text { Attribution License. }\end{array}$} \\
\hline \multicolumn{2}{|l|}{ Read online: } \\
\hline 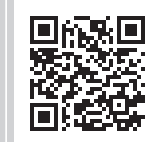 & $\begin{array}{l}\text { Scan this QR } \\
\text { code with your } \\
\text { smart phone or } \\
\text { mobile device } \\
\text { to read online. }\end{array}$ \\
\hline
\end{tabular}

Orientation: The South African Insurance Act 18 of 2017 became effective on 01 July 2018 as part of the new Twin Peaks regulatory system. The often stated reason for the new regulatory regime is the 2008 global financial crisis. Regulatory changes in the local environment took place during two distinct periods in history following the Sharpeville and Soweto uprisings in 1960 and 1976. International sanctions combined with an outflow of capital ultimately saw government amending the regulatory framework through new ownership requirements for all insurers in order to secure funds locally.

Research purpose: The purpose of this research was to explain how the contextual dynamics impacted regulatory responses, and what was the subsequent effect on the short-term insurance industry.

Motivation for the study: The motivation for the study was to explain and understand market dynamics following the regulatory tightening of the insurance industry within a historical framework.

Research approach/design and method: This article provides an empirical analysis of how regulatory intervention transformed market characteristics and thus contributed to an understanding of the localisation of a financial industry, namely the short-term insurance industry. This was achieved through a description of the regulation, including the exploration of possible consequences at the time of two major events in history.

Main findings: In both cases the findings were that the market size contracted, corrected and expanded within a few years.

Practical/managerial implications: This article provides a practical analysis of local industry performance in an environment of legislative changes which may assist managers in a regulated industry.

Contribution/value-add: The contribution is an industry analysis over an extended time frame which may add value in the adoption of similar domestication policies in the rest of Africa.

Keywords: domestication; foreign insurers; insurance; local insurers; regulation.

\section{Introduction}

Regulatory and legislative changes are considered as one of the top 10 risks facing financial institutions, and this is mainly because of the high costs associated with achieving compliance such as security and reporting obligations, including failures, which potentially result in large fines (Aon Risk Solutions 2017:3-24). Within 2 years, this ranking has fallen from number 4 to 10, which Aon Risk Solutions attributed to deregulation efforts of pro-business politicians in many parts of the world. Aon Risk Solutions $(2019: 3,8)$ considered this risk as underrated.

Financial regulation aims to maintain market confidence, financial stability and protect consumers and the public at large. The concept 'regulation' connotes the intervention of the state in human affairs which are structured from 'institutions' and may arise from political processes at national levels (Richardson \& Kilfoyle 2009:318). The public interest theory put forward the notion of the state intervening in otherwise well-functioning markets, usually capable of efficiently allocating resources, sometimes failing to achieve such rational allocation. This is the result of information asymmetries or monopoly power (Richardson \& Kilfoyle 2009:319-320; Williamson 1985). The 'public interest' may thus persuade the state to intervene in markets; as in this case, it was indeed the conviction of the state in the interest of protecting strategic financial resources of South Africa in the wake of international adversity. 
In 2017, the Insurance Act 18 of 2017 was published, 19 years after its predecessor, which provides an ideal opportunity to discuss the South African regulatory framework. The act revised the framework in which branches of foreign reinsurers operate and introduced regulatory approval for insurers to conduct insurance business outside the country. Regulation of insurance companies to stabilise the industry is not new and an explanation of the internalisation of the industry in 1914 provided a framework of the UK and France regulatory status, the former for its similarities to the South African legislative environment and the latter to demonstrate how economic nationalism modified the market.

In this article, the impact of state regulation on the short-term insurance industry is considered by reflecting on both industry and a case study performance. Between 1960 and 1980, two distinct periods of political instability occurred. This prompted state intervention via regulation and the impacts on the industry were measured in terms of several indices such as number of insurers, premium and assets. The results of Santam, a local insurer operating within a domesticated insurance environment, were analysed to determine the direct effect of regulation on performance.

South Africa became a Republic in May 1961. The period leading up to this historic event was dominated by rising domestic opposition to racial segregation, because the black majority of the population were excluded from participation in the Union Parliament. The Sharpeville incident was a turning point in South Africa's history, prompting the United Nations to call on the South African government to abandon its domestic policy of racial segregation. Mounting international criticism of the domestic policies and a flight of private capital resulted in a net capital outflow of R248 million between January 1960 and June 1961 and a decline of R173 million in gold and foreign exchange reserves in the corresponding period (Davenport \& Saunders 2000:415-416). This impacted the regulatory framework of the entire financial services industry, as the state sought to protect the industry and the country's financial resources, which were considered to be of strategic importance.

A similar economic intervention was seen in response to the 1976 riots. A statement issued by the Ministry of Finance and Economic Affairs highlighted decline in the net inflow of foreign capital, and monetary and fiscal measures were announced to strengthen the balance of payments such as a temporary imposition of deposits on imports (South African Reserve Bank [SARB] 1976:16). Again in 1979, the SARB reported a substantial net outflow of capital, which amounted to R3082 million and mainly comprised short-term capital from the private sector (SARB 1980:14).

It is concluded in this article that increased regulation in the short-term insurance industry resulted in major shifts in the composition and registration of insurers, yet industry and individual company performance was not directly compromised.

\section{Regulatory intervention Internationalisation and regulation post-1914}

A comprehensive analysis of regulatory regimes before 1914 was performed by Pearson and Lönnborg (2008:83), and it was found that insurance companies favoured regulation as it introduced certainty in a foreign business environment. Duties, licensing requirements, taxation, deposit requirements and reporting obligations were the measures imposed on foreign companies in many territories; this was also evident in South Africa from the turn of the 19th century to this period under review. Regulatory regimes before 1914 moved along a spectrum during different times, demonstrating a growing trend to monitor regulatory regimes and international standardisation before 1914 .

The historical perspective of the UK market provided an understanding of the South African situation because of similarities in both markets. Regulation in the UK after World War II was based on the old Victorian principle of 'freedom with publicity' with the onus on policyholders and shareholders to use the published information to monitor companies whilst companies regulated themselves. This model came under pressure in the 1960s with dubious entrants in the motor insurance market, large claims and market failures as well as the tariff crises of the 1970s, which led to the abolishment of the Fire Offices' Committee (FOC). This caused tightening of regulation and the Insurance Companies Act of 1974 was passed, closely followed by Policyholder Protection Act, which ultimately made government responsible for company behaviour. The strong overseas orientation since the Victorian era was reversed by 1990 with the home market accounting for $61 \%$ of UK insurance company business, mainly because of mergers and acquisitions, which forced reorganisation of larger companies (Pearson 2012:88-90).

France is an example where economic nationalism modified the insurance market. Between 1930 and 1938, measures were taken to codify and regulate the French insurance industry and restrict abusive practice, which led to collaboration between the profession and the government. World War II saw an expansion of insurers to foreign markets, targeting countries of the Union Française. Subsequent independence of most of these countries saw French insurers remaining but at reduced competitiveness compared to domestic insurers. Protectionist policies in these countries forced French insurers to focus on the home market, leaving foreign business down to $6.2 \%$. Between the 1950s and 1966, France targeted new countries via investment in foreign companies, including as subsidiaries, such as industrialised markets, including their neighbours Belgium, Italy and Spain. They retained their role in historic markets via technical expertise or reinsurance. From the 1970s, French insurers focussed on and grew faster internationally than the domestic markets with operations abroad growing from $11 \%$ in 1969 to $15 \%$ in 1980 (Straus 2012:130-136).

In South Africa, the insurance industry was less regulated at the beginning of the 20th century, with the market being open to domestic and foreign companies. The earliest 
legislation affecting short-term insurers was promulgated in 1891. The Cape Colony legislation required registration, payment of a deposit and furnishing of annual returns to the colonial treasury. After unification in 1910, statutory regulation of the insurance industry was not a priority. Statutory regulation, aimed at short-term insurers, was only promulgated as the Insurance Act, No. 37 of 1923. Insurers were required to register, furnish annual returns, be licensed and invest in a set amount of securities. The latter amounted to a maximum of $£ 10000$, furnished in cash or approved securities. This act focussed primarily on registration, the form, method and the extent of disclosures required with its principle aim to compel business to account to Government and to protect policyholders (Benfield 1997:568-594).

The basic regulatory framework did not change fundamentally as the Insurance Act, No. 27 of 1943, was promulgated. This act increased minimum asset requirements for Union and non-Union insurance companies. Assets within the Union had to equal liabilities, and permissible assets were extended significantly such as mortgages on immovable property, stocks in companies, stocks of local and other government authorities. These requirements introduced a compulsory investment element and tied foreign short-term insurance companies to investment in domestic state bonds. There was a distinct movement towards greater state oversight over the range of investments of insurance companies operating in South Africa.

The first Registrar of Insurance, George Beak, was appointed in terms of this act, reporting to the Minister of Finance. The day-to-day administration of the act was the responsibility of the Financial Institutions Office in Pretoria. The Registrar wanted policyholder protection, at the same time allowing insurers the freedom to develop and improve services (Benfield 1997:568-594). Insurance companies generally struggled to comply with the minimum asset investment provisions set by the act. Between 1959 and May 1963, a number of Union and non-Union insurers were in breach of the assets requirements of sections 17 and 18 of the Insurance Act (Registrar of Insurance 1959:3).

As international pressures and the domestic volatility after Sharpeville intensified, the state sought to secure control over the financial resources of the country. Insurance companies held extensive premiums, available for transfer to assets but, as joint-stock companies, ultimately paid out as dividends to foreign shareholders. This constituted a visible capital outflow the state sought to reverse. An important step in keeping revenue earned in South Africa was to 'domesticate' the insurance industry. This strategy was aimed specifically at the predominantly foreign-owned short-term insurance enterprises and implied an end to foreign control of many companies operating in South Africa over many decades.

The Insurance Amendment Act, No. 10 of 1965, changed section four of the 1943 Act by prohibiting any insurer from conducting insurance business unless registered as a South African company, although exceptions applied (South Africa Government 1965:90). Foreign insurers were compelled to register in South Africa and comply with the South African Companies Act, No. 46 of 1926, and hold security of the larger of R100 000 or $10 \%$ of the net premium payable in South Africa and in the local currency. Previously, foreign insurers could furnish approved securities with the Union's high commissioner in London, the Union's accredited representatives or high commissioners in Australia, Canada or New Zealand.

Intervention by the state via the introduction of 'regulation' to keep premium income in the market of origin was in response to market distortion caused by international adversity against South Africa, which jeopardised the flow of foreign investment into the country. The state used regulation of, inter alia, its insurance industry to secure control over domestic savings and premiums. Statutory controls were added to improve the solvency requirements, such as short-term insurers were required to hold $30 \%$ of their assets (as a percentage of net liabilities) in accordance with the Insurance Amendment Act, No. 41 of 1966, in Part I assets of which $10 \%$ had to be held in government securities (Registrar of Insurance 1966:2, 3). Part I assets were compulsory and changed as legislation changed but generally included money; money in a banking institution, or the National Finance Corporation as defined in the respective Acts; bills, bonds or securities guaranteed by government; bills, bonds or securities issued by any local authority; bills, bonds or securities issued or guaranteed by the Rand Water Board, the Electricity Supply Commission or as sanctioned by the Registrar. This system of prescribed assets as acceptable security was sustained in different forms since 1908 and remained until 1986.

Sharp rise in newly registered short-term insurance companies during the last half of the 1960s was primarily registrations as foreign branches converted into registered companies. A significant number of short-term insurance businesses were therefore transferred in early 1965 from foreign branches into local companies. Examples include the transfer of Law Union and Rock Insurance Co. Ltd. to the London \& Lancashire Insurance Company of South Africa Ltd., registered on 01 January 1966 and North British \& Mercantile Insurance Company Ltd., transferred to Commercial Union Assurance Company of South Africa Ltd. registered on 30 June 1965. By June 1965, the number of shortterm insurance companies rose to 26 , as 17 new insurers were registered (Registrar of Insurance 1966:2,14).

Insurers struggled to comply with the requirements of the act and by 1967 the Registrar reported that between 01 August 1965 and 06 December 1967, 31 insurers were found noncompliant, five insurers transferred their businesses and 26 cases were granted extended timeframes to comply with the more stringent financial requirements of the act (Registrar of Insurance 1967:3). The number of foreign-owned short-term insurance companies operating as branches of companies incorporated abroad dropped from 80 to 35. Only 23 were actively operating in the Republic as the majority were acquired by subsidiaries or domestic insurers (Registrar of Insurance 1969a:5, 1969b). The number of 'new' entrants in 
the market shows market domination by foreign companies, which was the reason for state concern over domestic financial resources.

A commission of enquiry into the financial structure and fiscal and monetary policies of South African authorities was appointed in 1967 under chairmanship of Dr D.G. Franzsen. The purpose of the enquiry was to propose measures that would promote economic growth and financial stability in the Republic. Foreign-controlled insurers were also included in the enquiry that at the time controlled $56 \%$ of the total short-term insurance assets. The government wanted the industry to be localised with $100 \%$ share capital available to South Africans. Another goal was to retain funds locally and to optimise tax receipts in the Republic. The commission recommended to encourage distribution of shares to South Africans all existing foreign insurance business had to be incorporated in the Republic and existing branches had to be converted into local companies within a period of 3 years which would be subsidiaries of foreign insurers (Franzsen Commission 1970:217-221).

The Franzsen Commission recommendations were finally incorporated in the Financial Institutions Amendment Act, No. 101 of 1976, compelling the conversion of foreign insurers into domestic insurers by 01 August 1979. To further improve the stability of the industry, solvency margins were increased and assets had to exceed liabilities by R100 000 or 10\% of net premium income to the maximum of R200 000 or $10 \%$. Within a year, the Financials Institutions Amendment Act, No. 94 of 1977 , required short-term insurers to increase this assets ratio substantially in government stock to $17.5 \%$ and Part I assets to $35 \%$ as a percentage of net liabilities, effective from 31 March 1978 (Registrar of Insurance 1977:3, 4).

Another reason for the regulation of assets held by the South African industry was for government to secure the investment funds of both short-term and life insurers to fund local industrial development whilst the country was affected by international sanctions. The investment of these assets had a stabilising effect on the general macro-economic development of the economy. The primary rationale for this statutory change was therefore to protect South Africa's strategic financial services sector, of which the insurance sector formed a key part (Verhoef 2010:147, 159). The short-term industry did not have the same impact as the long-term industry because of the significantly smaller comparative size of industry reserves (characteristic of short-term industry). Between 1960 and 1980, short-term assets varied between $8.6 \%$ and $11 \%$ of long-term assets (Table 2 ).

According to Benfield (1997:568-594), legislation prior to unionisation was protectionist but over the century had become controlling and inhibitive. This is confirmed as the powers of the Registrar were extended in the latter part of the 1970s, such as the capacity to declare a method of conducting business as 'irregular' or 'undesirable' and overseeing the legitimacy of operators in the insurance business. The stricter solvency requirements introduced in 1978 were subsequently relaxed and expansions were re-introduced in stages (Registrar of Insurance 1979:2, 4). Inspection of insurance companies and intermediaries contributed to a stable industry environment with fewer company failures compared to the 1960s. The insurance industry also became more regulated as further amendments to the act were introduced by the Financial Institutions Amendment Acts, Nos. 75 of 1970, 80 of 1978 and 99 of 1980.

\section{Consequences of regulatory changes on insurance industry Number and asset composition of insurers}

The number of insurers registered outside the country declined significantly from 90 to 26 between 1960 and 1970, as depicted in Table 1. The largest British branches were converted into registered offices in the Union, and the Royal Globe Group concluded that they would operate entirely through South African registered and quoted companies, and it was registered in the Republic on 09 September 1965 (Vivian 1995:78-80).

In 1961, the Franszen Commission (1970:217) provided valuable insight into the ownership of insurance industry: 24 of the 140 registered insurers were controlled by local noninsurance parent companies; 17 were controlled by other local insurers; 70 were controlled by foreign parties and 11 were mutuals and 18 were independent. By 1970, the buoyancy in the insurance industry could be observed in the number of new registrations, cancellations and extensions into new classes of insurance by existing insurers. Mutual and Federal Insurance Holdings Limited was registered on 21 December 1971 for all classes of short-term insurance. Many British insurers cancelled their registrations, such as the Liverpool and London Insurance Company, and the London and Lancashire Insurance Company, as they were incorporated (consolidated) into the local Mutual and Federal (Vivian 1995:67). Measured over a period of three decades, the overall total number of insurers, including life insurers, contracted by almost $50 \%$ from 172 in 1950 to 90 in 1980, as depicted in Table 2.

The assets held locally increased dramatically as a direct result of the statutory investment requirements introduced during 1965 and there was a significant shift in prescribed securities such as government stock, public corporation and local stocks, as depicted in Table 1.

In 1950, foreign insurers' assets were almost double that of Union's insurers. Assets measured as a percentage of gross

TABLE 1: Annual changes in assets of insurers and private pension funds (R millions).

\begin{tabular}{lcccccc}
\hline Prescribed assets & 1963 & 1964 & 1965 & 1966 & $1967 \dagger$ \\
\hline Government stock & -1 & -15 & +3 & +71 & +71 \\
Public corporation, local authority, stock and loans & +54 & +71 & +75 & +50 & +74 \\
Total prescribed securities & +53 & +56 & +78 & +121 & +145 \\
\hline
\end{tabular}

Source: South African Reserve Bank (SARB), 1968, Quarterly statistical bulletins, p.15, South African Reserve Bank, Pretoria.

$\dagger$, Adjusted to annual rate. 
TABLE 2: Number of assets of insurance companies 1950-1980.

\begin{tabular}{|c|c|c|c|c|c|c|c|c|}
\hline $\begin{array}{l}\text { Year-end of } \\
\text { insurer ('000) }\end{array}$ & $\begin{array}{c}\text { No. of life and } \\
\text { short-term foreign } \\
\text { insurers }\end{array}$ & $\begin{array}{l}\text { No. of life and } \\
\text { short-term local } \\
\text { insurers }\end{array}$ & $\begin{array}{l}\text { Total No. of life } \\
\text { and short-term } \\
\text { insurers }\end{array}$ & $\begin{array}{l}\text { Total short-term } \\
\text { assets }\end{array}$ & $\begin{array}{l}\text { Total long-term } \\
\text { assets }\end{array}$ & $\begin{array}{l}\text { Short-term †as } \\
\% \text { of long-term } \\
\text { assets }\end{array}$ & $\begin{array}{l}\text { GDP at current } \\
\text { prices ('000 } \\
\text { millions) }\end{array}$ & $\begin{array}{l}\text { Short-term } \dagger \\
\text { assets as \% } \\
\text { of GDP }\end{array}$ \\
\hline 1950 & 84 & 88 & 172 & f20 144 & f192963 & 10.4 & $£ 1313$ & 1.5 \\
\hline 1960 & 90 & 91 & 181 & f53 173 & $£ 481593$ & 11.0 & R5349 & 2.0 \\
\hline 1965 & 80 & 17 & 97 & R139 560 & R1409 000 & 9.9 & R8071 & 1.73 \\
\hline 1970 & 26 & 100 & 126 & R384 658 & R2900000 & 13.3 & R12 400 & 3.1 \\
\hline 1980 & 1 & 89 & 90 & R1 240789 & R14 395000 & 8.6 & R62 397 & 2.0 \\
\hline
\end{tabular}

Source: Compiled from Republic of South Africa Annual Reports of the Registrar of Insurance (1952:66, 1955:19, 20, 1963:6, 1967:14, 1972:15, 16, 1977:38, 1982:38); SARB (March 1956 to December 1957:35, 1960 and 1965:S60, 1970 and December 1971:66, 1975 and 1980:S8); Union of South Africa (1960:R-15), the long-term assets and 1950 GDP statistics were derived from 1965; Verhoef (2010:156)

Notes: $\dagger$, Short-term exclusive of registered foreign and domestic professional reinsurers; from 1949 to 1961 premium after deduction of approved reinsurance excluding former insurers. The years are in accordance with the year-end of insurers on 31 December of each year. GDP, gross domestic product.

\begin{tabular}{|c|c|c|c|c|c|c|c|}
\hline & 1950 & 1955 & 1960 & 1965 & 1970 & 1975 & 1980 \\
\hline \multirow{2}{*}{ Total union insurer income } & - & - & - & ${ }^{\prime} 000$ & ‘000 & $` 000$ & $` 000$ \\
\hline & £3251292 & $£ 3398546$ & $£ 13379701$ & R35 524 & R146 619 & R331 059 & R785 826 \\
\hline Total non-union insurer & $£ 7784332$ & $£ 16552979$ & $£ 25188024$ & R62 331 & R13 828 & R12 641 & Ro \\
\hline Total short- term insurers & $£ 11035624$ & $£ 11951525$ & $£ 38567725$ & R97 855 & R160 447 & R343700 & R785 826 \\
\hline \multirow{3}{*}{ Price index } & Wholesale 197.6 & Wholesale & CPI & CPI & CPI & CPI & CPI \\
\hline & $1938=100$ & 271.5 & $1.30 \%$ & $3.30 \%$ & $5.30 \%$ & $12.30 \%$ & $15.80 \%$ \\
\hline & - & $1938=100$ & - & - & - & - & - \\
\hline Ratio union to total insurers & $29.5 \%$ & $24.5 \%$ & $34.7 \%$ & $36 \%$ & $91 \%$ & $96 \%$ & $100 \%$ \\
\hline
\end{tabular}

Source: Compiled from returns furnished to the Registrar of Insurance (1955:21, 1957:15, 18, 1962:17, 24, 1967:29, 1972:28-30, 51, 1977:51, 1982:38) and www.inflation.eu/inflation-rates/southafrica/historic-inflation/cpi-inflation-southafrica.aspx

Notes: CPI, Consumer Price Index. 1970-1980 Net retention is shown, excluding all professional reinsurers. Wholesale price index to 1959 was compiled from Union of South Africa Statistics for fifty 50 years, $(1960: \mathrm{H}-15)$. The inflation rate is based on the CPI. From 1960 onwards, the annual inflation for South Africa is shown comparing the December CPI, annually, with the CPI of the previous year. Premium derived in the Republic only. Net income includes reinsurance.1975 Premium is the gross premium.

FIGURE 1: Short-term net premium income in South Africa, 1950-1980.

domestic product (GDP) remained unchanged at $2 \%$ between 1960 and 1980, notwithstanding the 1965-enactment.

It cannot be claimed that more stringent regulations curtailed the industry as the total premium income and assets furnished by the short-term industry grew at a sustained rate between the enactments of the domestication requirements and the end of this period under review. In addition, shortterm premium measured as a percentage of national income displayed a sustained growth trajectory. ('Domestication' is a common term adopted by the insurance and reinsurance industries for the transition of insurance companies from overseas companies and branches to locally registered entities. The term was formally adopted in 1969 by the South African Registrar of Insurance.)

\section{Premium income}

Contraction in the number of insurers did not appear to have impacted the industry performance, measured in terms of total premium income (Figure 1). Foreign insurers dominated the short-term insurance market in 1950, collecting $70.5 \%$ of total net premium income. After the passing of the Insurance Amendment Act, No. 10 of 1965, premium income in
South Africa grew by $700 \%$. This represents a compound annual growth rate of $14.9 \%$ and is significant notwithstanding the rise in inflation during the late 1970s (Figure 1).

The South African economy thrived after World War II aided by international economic reconstruction and supported GDP growth (at constant prices) of $8.5 \%$ per annum between 1948 and 1970 (Feinstein 2005:9). By 1980, the rate of increase in real GDP amounted to about 8\% (SARB 1981:6). The South African economy entered a period of exponential growth during mid-1961 (Jones \& Müller 1992:129, 231). This unprecedented growth was attributed to government intervention by means of an inward-looking industrial policy providing protection to local industries through import control, subsidies, blocked repatriation of profits earned by foreigners and tight controls on export of capital (Davenport \& Sanders 2000:415-416). In this context of political turbulence and relatively strong economic performance, the regulatory environment of the financial service sector was bound to receive close government scrutiny.

The national significance of the short-term industry to the national economy is depicted in Figure 2, measured in terms of the proportion of total net premium to national 


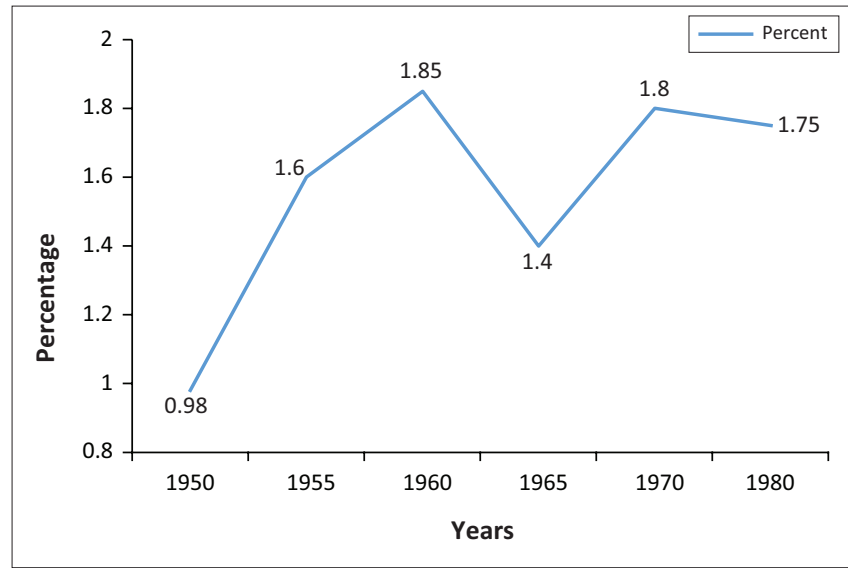

Source: Compiled from Reports of the Registrar, and SARB 1982:21-24

FIGURE 2: Short-term premium as a percentage of national income 1950-1980.

income. This contribution dropped considerably to $1.4 \%$ in 1965 and could be attributed to either market contraction because of recent regulatory impositions or contracting economic conditions. Domestication did not curtail the growth of local industry, as reflected in the fairly static proportion of premium income to national income between 1960 and 1980.

\section{The case study of Santam Insurance: Institutional and regulatory impacts on a local insurer}

The objective of this case study review is to determine if the strengthening of regulatory controls to localise an industry impacted the performance of a local insurer. Santam Insurance is a local short-term insurer established during 1918 by a local group of men determined to grow the economy and stem the outflow of fire premium to foreign, mostly British, parent companies. In the chairman's address at the first annual general meeting (AGM) held in 1919, Hofmeyr confirmed the reason for its establishment: 'The Company is established exclusively with South African capital, so that all profits will remain in the country' (Santam Insurance 1968:1-2).

\section{Company structure}

The historical development of this company from humble beginnings to market leader could be explained within the framework of Chandler's (2002) study of enterprise development. Chandler (2002:1) noted that modern American enterprise consisted of 'many distinct operating units and it is managed by a hierarchy of salaried executives'. Traditional enterprise was characterised by a small number of owners operating from a single office, performing one economic function, focussed on one product line in one geographical area. Whilst the small traditional enterprise was affected and coordinated by market and price mechanisms, salaried employees coordinated the modern enterprise. The enterprise structure expanded into several units under professional management control, operating over a larger geographical area and coordinating various types of economic activities
(Chandler 2002:1-3). This observation held equally for the short-term insurance company, Santam.

Santam started as a modern enterprise just after World War I. The executive management comprised a group of salaried employees. The Dagelijks Bestuur (executive committee) comprised chairman of the board, three directors and a general manager. This management team met once a week, oversaw every aspect of the business and appointed middle management such as McDowall an 'insurance manager' to report to senior management, who were salaried employees (Verhoef \& Drotskie 2015:251-275).

\section{The growth of an enterprise within a regulated environment}

Santam showed low yet consistent growth since its establishment. By 1952, on a national scale, it ranked seventh out of a total of 108 foreign and local insurers operating in the Union. Measured in terms of local short-term premium, Santam comprised only $11.4 \%$ or $£ 506557$ of the total market premium of $£ 4444275$ (Registrar of Insurance 1952:17-18). By 1955, Santam achieved a major milestone when its gross premiums exceeded $£ 1000000$. At the time, the largest local insurer was African Guarantee with Santam ranked the second largest out of 27 South African fire insurers.

Management made no reference to potential adverse effects of foreign investment following the Sharpeville riots. By 1967, Santam was ranked first amongst domestic short-term insurance companies, reporting an annual income of R6 889 000, followed by S.A. Eagle group at R6 569000 and Rand Mutual at R5 477000 (The Cape Argus 1967:13). C.H.J. Van Aswegen, chairman of the Santam board, in a private letter to C.R. Louw, chairman of Santam, confirmed the results for 1964, and that (gross - my insertion) income had almost doubled to R11 948000 by 1966 (Van Aswegen's letter to Louw 06 March 1967). Louw remarked that Santam was the only Afrikaans institution that had achieved such a success in a highly competitive market of 31 local and 61 foreign insurers, and described this as 'a truly remarkable achievement' (Letter of Van Aswegen to Louw 1967). In terms of net premium income, specialist insurer Rand Mutual continued to dominate the industry. A record profit of R2 000000 was posted by the Santam group for the following year ending 30 September 1967; assets had increased by R10 800000 and fixed deposits by R13 000000 (Santam Insurance 1968).

The net profit of Santam Insurance (1956-1980) grew exponentially during two distinguishable periods, namely 1962-1967 and 1972-1974, as depicted in Table 3. These periods of growth coincided with the introduction of regulatory restrictions to ensure domestication of the insurance industry as well as economic growth. Notwithstanding the volatile growth pattern, Santam posted an impressive increase of $4968 \%$ in net profit between 1961 and 1980. This translates into an average annual increase of 261\% between 1962 and 1980, but needs to be moderated by 
the tide of rising inflation. Considering the $12.2 \%$ annual compound growth of Santam's profitability, the company was outperforming GDP growth but was on par with the short-term industry performance at $13.3 \%$. It took the company 30 years to earn gross premium income of $£ 420501$, and nine short years to reach $£ 1723$ 191. This achievement was considered a phenomenal achievement, particularly in view of keen competition that had driven premiums down.

Santam Insurance entered a period of negative growth by 1975 , yet by 1976, measured in terms of premium income, was ranked the largest short-term insurer in the Republic of South Africa. Net profit growth was corrected only in 1980 (Table 3). By the late 1970s Santam had expanded to other financial institutions and was a holding company to several banks, other short-term insurance companies and related insurance businesses.

Santam did not acquire any branches of or foreign insurers during the 'domestication' transition. Therefore, it cannot be argued that Santam's performance was the outcome of the acquisition of foreign insurers compelled to incorporate in the local market following local regulatory domestication. Instead, Santam introduced innovative insurance products such as the multiplex policy which escalated its performance

TABLE 3: Santam's net profit from 1961 to 1980.

\begin{tabular}{lccc}
\hline Year & Net profit (South African rand) & Growth (\%) & Consumer price index (\%) \\
\hline 1961 & 133660 & $(34)$ & - \\
1962 & 237100 & 77 & - \\
1963 & 515000 & 117 & - \\
1964 & 600600 & 166 & - \\
1965 & 601000 & 0 & 3.32 \\
1967 & 1393700 & 132 & - \\
1968 & 1446800 & 4 & - \\
1969 & 1581000 & 9 & - \\
$1970 \dagger$ & 1352100 & $(14.4)$ & - \\
$1972 \dagger$ & 1865000 & 38 & - \\
$1973 \dagger$ & 2926800 & 57 & - \\
1974 & 4373600 & 48 & 12.28 \\
1975 & 4327300 & $(1)$ & - \\
1977 & 3255100 & $(25)$ & 15.84 \\
\hline 1980 & 6774300 & 108 & - \\
\hline
\end{tabular}

Source: Compiled from Santam Insurance (1956-1980), Annual Reports to shareholders Notes: From 1974, net profit after adjustments/tax provisions, including unappropriated profit. 'Group profit' is as presented in each of the annual financial statements of the relevant year as ownership structures and reporting requirements changed. Consumer pric index (CPI): From 1960 onwards, the annual inflation by year for South Africa is shown comparing the December CPI, annually to the CPI of the previous year (Inflation data: Viewed 21 February 2017, from https://www.inflation.eu/inflation-rates/south-africa/ historic-inflation/cpi-inflation-southafrica.aspx).

Data set in brackets are values which are compared to the preceding year.

$\dagger$, Santam Bank Group consolidated financials only. phenomenally during the 1970s. The important indicators are highlighted in Table 4 . The performance of Santam as a local representative of the financial services industry between 1960 and 1980 presents an image of stability. In all categories of reporting, Santam significantly exceeded local GDP growth.

\section{Conclusion}

When South Africa became a Republic in 1961 and domestic policies of separate development sustained, a new phase commenced in the history of the South African insurance industry. The transition of this local market was consequently prompted by economic and regulatory intervention to domesticate the industry and internalise assets to achieve national stability and growth. The number of foreign shortterm insurers declined from 90 in 1960 to only 1 in 1980 and all foreign assets furnished as security were consequently restricted to the Republic. The introduction of this form of regulation did not affect the industry performance (measured in terms of premium income, national income and contribution to GDP). Regulation as a market correcting instrument used by the state was in fact a response to market distortion brought about by its own domestic policies of separate development. The stability of performance of the short-term insurance sector, as well as the case of Santam, testifies to the soundness of the industry, both local and foreign firms. Regulation to secure domestication of the short-term insurance sector did not injure the industry but could have boosted the performance of traditional South African companies such as Santam and Mutual and Federal. This demonstrates the localisation of an industry formerly dominated by foreign insurers over a period of almost three decades. Domestication also ensured regulatory oversight, which contributed to the stable and sustained growth of the short-term insurance industry. Santam was exceptionally successful in translating later entry into strong growth and a leading industry position by the late 1980s.

\section{Acknowledgements}

The authors would like to thank Claudia Boffard for editing of the original thesis. The article is substantially derived from a thesis by Y. Hagedorn-Hansen 'Transformation of the South African short-term industry: The case of Santam, 1918-2011'.

\section{Competing interests}

Prof. G Els is an author and also editor of JEF.

TABLE 4: Growth of Santam between 1961 and 1980 (in South African rand).

\begin{tabular}{lccccc}
\hline Year & Net profit before tax & General reserves & Assets & Gross premium & Net premium \\
\hline 1961 & 163741 & 565000 & 4832096 & Not applicable \\
1965 & 601000 & 800000 & 7933800 & 6388000 \\
1970 & 1339700 & 1400000 & 20439900 & 21300000 \\
1975 & 4327300 & 1400000 & 51546300 & 475000 & 405000 \\
1980 & 6774300 & 10000000 & 118584600 & 168971797 \\
Annual compound growth rate (\%) & 110.54 & 77.66 & 89.66 & 126762000 \\
\hline
\end{tabular}

Source: Compiled from Santam Insurance (1956-1980) annual accounts from 1961 to 1980

Notes: Gross premium was derived from Annual Reports to Registrar from 1965 to 1975, net premium 1980. 


\section{Authors' contributions}

Y.H.-H. was the researcher of the original thesis from which this article is substantially derived. Y.H.-H. was also responsible for the first version of this article and substantial editing and additional research. Both G.V. and G.E. were cosupervisors of the original work and their involvement in this article included substantial subject-matter contribution, including editorial changes and overview.

Approval was provided by all three authors for publication of the final version of the article.

\section{Ethical considerations}

This article followed all ethical standards for research without direct contact with human or animal subjects.

\section{Funding information}

A submission cost was covered by the Department of Accounting, University of Johannesburg, South Africa.

\section{Data availability statement}

Data sharing is not applicable to this article as no new data were created or analysed in this study.

\section{Disclaimer}

The views expressed in this article are the authors' own and not an official position of the institution or funder.

\section{References}

Aon Risk Solutions, 2017, Global risk management survey, Aon Risk Solutions, London viewed 08 September 2019, from https://www.aon.com/2019-top-global-risksmanagement-economics-geopolitics-brand-damage-insights/index.html.

Aon Risk Solutions, 2019, Global risk management survey, Aon Risk Solutions, London, viewed 08 September 2019, from https://www.aon.com/2017-global-riskviewed 08 September 2019,
management-survey/index.html.

Benfield, B.C., 1997, 'The South African life assurance legislation: A survey', The South African Journal of Economics 65(4), 568-594. https://doi.org/10.1111/j. 1813-6982.1997.tb01380.x

Chandler, A.J., 2002, The visible hand. The managerial revolution in American business, Harvard University Press, London.

Davenport, T.R.H. \& Saunders, C., 2000, South Africa: A modern history, Palgrave Macmillan, Hampshire.

Feinstein, C.H., 2005, An economic history of South Africa. Conquest, discrimination and development, Cambridge University Press, Cambridge.

Franzsen Commission, 1970, Third report of the Commission of Enquiry into Fiscal and Monetary Policy in South Africa, Franzsen Commission, Pretoria.

Jones, S. \& Müller, A., 1992, The South African economy, 1910-90, Macmillan, London.

Pearson, R., 2012, 'United Kingdom: Pioneering insurance internationally', in P. Borscheid \& N.V. Haueter (eds.), World insurance. The evolution of a global risk network, pp. 88-90, Oxford University Press, Oxford.

Pearson, R. \& Lönnborg, M., 2008, 'Regulatory regimes and multinational insurer before 1914', The Business History Review 82(1), 59-86. https://doi.org/10.1017/ S000768050003751X

Registrar of Insurance, 1952, Registrar of Insurance: 7th annual report of the Registrar of Insurance which embodies a summary of returns lodged by insurers in respect of financial years ended during the calendar year 1950, UG10/1952, Published by authority.

Registrar of Insurance, 1955, Registrar of Insurance: 10th annual report of the Registrar of Insurance which embodies a summary of returns lodged by insurers in respect of financial years ended during the calendar year 1953, UG57/1955, Published by authority.

Registrar of Insurance, 1957, Registrar of Insurance: 12th annual report of the Registrar of Insurance which embodies a summary of returns lodged by insurers in respect of financial years ended during the calendar year 1955, UG50/57, Published by authority.

Registrar of Insurance, 1959, Registrar of Insurance: 14th annual report of the Registrar of Insurance which embodies a summary of returns lodged by insurers in respect of financial years ended during the calendar year 1957, UG28/59, Published by authority.
Registrar of Insurance, 1962, Registrar of Insurance: 17th annual report of the registrar of insurance which embodies a summary of returns lodged by insurers in respect of financial years ended 30/06/1961, RP42-62, Government Printing respect of financial years
Works (GPW), Pretoria.

Registrar of Insurance, 1963, Registrar of Insurance: 18th annual report of the registrar of insurance which embodies a summary of returns lodged by insurers in respect of financial years ended 30/06/1962, RP45-63, Government Printing Works (GPW), Pretoria.

Registrar of Insurance, 1966, Registrar of Insurance: 21st annual report of the registrar of insurance which embodies a summary of returns lodged by insurers in respect of financial years ended during the calendar year 1965, RP42'66, Cape Times, IOL, Pretoria.

Registrar of Insurance, 1967, Registrar of Insurance: 22nd annual report of the registrar of insurance which embodies a summary of returns lodged by insurers in respect of financial years ended 30/6/1966, RP83'67, Cape Times, IOL, Pretoria.

Registrar of Insurance, 1969a, Registrar of Insurance: 23rd annual report of the Registrar of Insurance which embodies a summary of returns lodged by insurers in respect of financial years ended 30/6/1967, RP19'69, Cape Times, IOL, Pretoria.

Registrar of Insurance, 1969b, Registrar of Insurance: 24th annual report of the Registrar of Insurance which embodies a summary of returns lodged by insurers in respect of financial years ended during the calendar year 1967, RP74'69, Cape Times, IOL, Pretoria.

Registrar of Insurance, 1972, Registrar of Insurance: 27th annual report of the registrar of insurance which embodies a summary of returns lodged by insurers in registrar of insurance which embodies a summary of returns lodged by insurers in
respect of financial years ended during the calendar year 1970, RP68/1972, Cape respect of financial y
Times, IOL, Pretoria.

Registrar of Insurance, 1977a, Registrar of Insurance: 32nd annual report of the Registrar of Insurance which embodies a summary of returns lodged by insurers in respect of financial years ended during the calendar year 1975, RP63/1977, Cape Times, IOL, Pretoria.

Registrar of Insurance, 1977b, Registrar of Insurance: 33rd annual report of the Registrar of Insurance year ended 31/12/1976, RP115/1977, Government Printing Works (GPW), Pretoria.

Registrar of Insurance, 1979, Registrar of Insurance: 34th annual report of the Registrar of Insurance year ended 31/12/1977, RP75/1979, Government Printing Registrar of Insurance yea
Works (GPW), Pretoria.

Registrar of Insurance, 1982, Registrar of Insurance: 37 th annual report of the Registrar of Insurance which embodies a summary of returns lodged by insurers in respect of financial years ended during the calendar year 1980, Cape Times, IOL, Pretoria.

Richardson, A.J. \& Kilfoyle, E., 2009, 'Regulation', in J.R. Edwards \& S.P. Walker (eds.), The Routledge companion to accounting history, Routledge, London.

Santam Insurance, 1968, Santam AGM chairman's address, 23 January 1968, Santam, Bellville, City of Cape Town.

Santam Insurance, 1956-1980, Annual reports to shareholders 1956-1980, Santam, Bellville, City of Cape Town.

South African Reserve Bank (SARB), 1956, Quarterly statistical bulletins, South African Reserve Bank, Pretoria.

South African Reserve Bank (SARB), 1957, Quarterly statistical bulletin, South African Reserve Bank, Pretoria.

South African Reserve Bank (SARB), 1960, Quarterly statistical bulletins, South African Reserve Bank, Pretoria.

South African Reserve Bank (SARB), 1965, Quarterly statistical bulletins, South African Reserve Bank, Pretoria.

South African Reserve Bank (SARB), 1968, Quarterly statistical bulletins, South African Reserve Bank, Pretoria.

South African Reserve Bank (SARB), 1970, Quarterly statistical bulletins, South African Reserve Bank, Pretoria.

South African Reserve Bank (SARB), 1971, Quarterly statistical bulletins, South African Reserve Bank, Pretoria.

South African Reserve Bank (SARB), 1975, Quarterly statistical bulletins, South African Reserve Bank, Pretoria.

South African Reserve Bank (SARB), 1976, Quarterly statistical bulletin September to December 1976, statement regarding the temporary imposition of deposits on imports on 21/7/1976, South African Reserve Bank, Pretoria.

South African Reserve Bank (SARB), June 1980, Quarterly statistical bulletins, South African Reserve Bank, Pretoria.

South African Reserve Bank (SARB), 1981, Quarterly statistical bulletins, South African Reserve Bank, Pretoria.

South African Reserve Bank (SARB), 1982, Quarterly statistical bulletins, South African Reserve Bank, Pretoria.

Straus, A., 2012, 'France: Insurance and the French financial networks', in P. Borscheid \& N.V. Haueter (eds.), World insurance. The evolution of a global risk network, pp. 130-136, Oxford University Press, Oxford.

Santam leads short-term insurance industry results, The Cape Argus Newspaper, 04 March 1967.

Union of South Africa, 1960, Union statistics for fifty years, Bureau of Census and Statistics, Pretoria.

Verhoef, G., 2010, 'Life offices to the rescue! A history of life assurance in the South African economy during the twentieth century', in R. Pearson (ed.), The development of international insurance, pp. 147-159, Pickering \& Chatto, London.

Verhoef, G. \& Drotskie, A., 2015, 'Sustained in a competitive environment: Organizational capabilities and Sanlam, 1918-1945', Management and Organizational History 10(3-4), 251-275. https://doi.org/10.1080/17449359.2015.1098548

Vivian, R.W., 1995, The story of Mutual \& Federal 1831-1995, Mutual \& Federal, Johannesburg.

Williamson, O.E., 1985, The economic institutions of capitalism, The Free Press, New York. 